\title{
Comparison of the Chronic Perceptions of Public and Private
} Business Employees

\section{Fatih Bedir ${ }^{*}$, Emre Belli', Murat Turan², Davut Budak ${ }^{1}$}

'Spor Bilimleri Fakültesi, Atatürk Üniversitesi, Erzurum, Turkey

${ }^{2}$ Ministry of Youth and Sports, Ankara, Turkey

Study Area: Erzurum, Turkey

Coordinates: $39^{\circ} 54^{\prime} 31$ ? N; $41^{\circ} 16^{\prime} 37$ ? E

\section{Abstract}

In this study, a data collection was used as a tool in the form of a survey comprised of 2 sections. In the first section, questions related to demographic characteristics; in the second section, were used a "Perceived Organizational Chronism". The data collection tools were applied to a total of 176 personnel ( 120 male, 56 female).

As a result of the analyzes, it was revealed that the Cronyism perceptions of the personnel offered in favour of women. Also, it was found that the chronological perception of the personnel differed in favour of public institutions according to the institution variable.

her power and authority to her advantage. Although there is not much difference between chronism and nepotism, people favored in chronism are not "relatives", but "friends", "friends", and the like (Aktan, 2001). As a result of chronism, while emotional bonds develop between members within the friendship group, negative consequences arise for the organization (Aytaç, 2010). In chronism, the tolerance given to friends and acquaintances is not given to other people and thus the principle of equality is treated against. As a result, the citizens' perspective towards the organization becomes negative (Erdem \& Meriç, 2012).

Aggregates in the organizational environment somehow initiate the power struggle. The power struggle between informal groups can lead to chronistic relations in the organization. Because this struggle can favor others who have power on the ground. In this regard, power can be seen as a resource that enables favoritism. Besides, favoritism turns into a tool used to increase the power of the authorized person from time to time. When managers have power resources, they use the authority they obtain from these sources in their relationships. In this case, managers use their authority power especially in the interests of those they trust. This action naturally results in favoritism (Asunakutlu, 2010).

It is possible to express the negative effects of favoritism as follows:

- It has many negative effects on people who are not favored. For example; their motivation decreases, their tendency to assurance decreases, their loyalty decreases, they adopt a behavior of silence, they do not share their ideas and suggestions in favor of their institutions.

- An atmosphere of conflict is experienced in the institution.

- It causes a climate of insecurity.

- Since the business does not act rationally, works are disrupted subordinates based on non-performance factors and using 
and growth slows down.

- Institutionalization cannot beachieved.

- Corporate imageand reputation are damaged.

- It cannot be expected that a business in which works are carried out without relying on the merit system to be long term.

- Businesses and people stay away from doing business with this business.

- Professionalization becomes difficult.

- Even in favoritism, there may be problems and conflicts such as little favored, very much favored (Büte, 2011).

In line with these explanations, the general purpose of the research is to examine the appointments made in public and private organizations in terms of merit.

\section{Materials and Methods:}

The universe of the research; While Erzurum Youth and Sports Provincial Directorate and Erzurum Polat hotel employees were formed; The sample group consisted of a total of 176 people, 120 men, and 56 women, randomly selected among them.

To measure the chronism information of the participants; The Perceived Organizational Chronism scale, which consists of 15 items and 3 sub-dimensions ("Inner group favoritism -Paternal chronism-Mutual interest exchange) was developed by Turhan (2013), was used. Frequency analysis to determine the demographic characteristics of the participants, t-test in independent groups in comparison of chronism perceptions according to gender, marital status, management background, institution, position in the institution; One-way analysis of variance to compare according to education, seniority and age variables; Tukey test was applied to find out which groups caused the difference and the significance level was taken as 0.05 .

\section{Results:}

Table-1: Demographic Characteristics of the Participants

\begin{tabular}{lllllll}
\hline Variables & Class & $\mathrm{N}$ & $\%$ & Class & $\mathrm{N}$ & $\%$ \\
\hline Age (years) & $18-25$ & 28 & 15.9 & $26-33$ & 44 & 25.0 \\
& $34-41$ & 56 & 31.8 & $\geq 42$ & 48 & 27.3 \\
Gender & Male & 120 & 68.2 & Female & 56 & 31.8 \\
Education & Primary & 7 & 4.0 & High School & 46 & 26.1 \\
& Asso. Deg. & 44 & 25.0 & & & \\
& Graduate & 66 & 37.5 & Post Graduate & 13 & 7.4 \\
Marital Status & Married & 125 & 71.0 & Single & 51 & 29.0 \\
Service Year & $1-5$ & 52 & 29.5 & $6-10$ & 69 & 39.2 \\
11-15 & 31 & 17.6 & $>15$ & 24 & 13.6 & \\
Position at the & Manager & 35 & 19.9 & Staff & 141 & 80.1 \\
Institution & & & & & & \\
Management & Yes & 52 & 29.5 & No & 124 & 70.5 \\
Experience & & & & & & \\
Employment & Public & 92 & 52.3 & Private & 84 & 47.7 \\
\hline
\end{tabular}

Table-1 is self explanatory.

When the data were examined, in comparing the chronism sub-dimensions related to the gender of the participants; a highly significant difference in In-group favouritism, Paternal chronism and Mutual exchange of interests sub-dimensions.

Table-2: Comparison of the participants' chronism scale scores according to the gender variable

\begin{tabular}{lllllll}
\hline & Gender & $\mathrm{N}$ & $\mathrm{X}$ & $\mathrm{ss}$ & $\mathrm{t}$ & $\mathrm{p}$ \\
\hline In-group & Male & 120 & 2.97 & 1.03 & -3.66 & .0oo* \\
favoritism & Female & 56 & 3.58 & 1.05 & & \\
Paternalchronism & Male & 120 & 2.66 & 1.11 & -3.21 & $.002^{*}$ \\
& Female & 56 & 3.28 & 1.32 & & \\
Mutual exchange & Male & 120 & 2.49 & .86 & -3.38 & .0o1* \\
of interests & Female & 56 & 3.00 & 1.09 & & \\
\hline
\end{tabular}

Table-3: Comparison of the participants' chronism scale scores according to the marital status variable

\begin{tabular}{lllllll}
\hline & Marital Status & $\mathrm{N}$ & $\mathrm{X}$ & $\mathrm{ss}$ & $\mathrm{t}$ & $\mathrm{p}$ \\
\hline In-group & Married & 125 & 3.19 & 1.10 & .510 & .610 \\
favoritism & Single & 51 & 3.10 & 1.00 & & \\
Paternalchronism & Married & 125 & 2.79 & 1.29 & -1.09 & .274 \\
& Single & 51 & 3.01 & .97 & & \\
Mutual exchange & Married & 125 & 2.56 & .99 & -1.98 & $.049^{*}$ \\
of interests & Single & 51 & 2.88 & .87 & & \\
\hline
\end{tabular}

While comparing the chronism sub-dimensions of the participants' marital status a significant difference in the sub-dimension of mutual interest exchange was evidenced (Table-3).

Table-4: Comparison of the participants' chronism scale scores according to the managerial experience variable

\begin{tabular}{lllllll}
\hline \multicolumn{2}{c}{ Managerial Experience } & $\mathrm{N}$ & $\mathrm{X}$ & $\mathrm{ss}$ & $\mathrm{t}$ & $\mathrm{p}$ \\
\hline In-group & Yes & 52 & 2.60 & .50 & -4.74 & $.000^{*}$ \\
favoritism & No & 124 & 3.40 & 1.16 & & \\
Paternalchronism & Yes & 52 & 2.05 & .88 & -6.37 & $.00{ }^{*}$ \\
& No & 124 & 3.20 & 1.17 & & \\
Mutual exchange & Yes & 52 & 1.92 & .66 & -7.40 & $.000^{*}$ \\
of interests & No & 124 & 2.96 & .91 & & \\
\hline
\end{tabular}

While comparing the chronism sub-dimensions of the participants' management experience, significant differences were found in sub-dimensions of in group favoritism, Paternal chronism, and also in mutual interest exchange (Table-4).

Table-5: Comparison of the participants' chronism scale scores according to the institutional variable

\begin{tabular}{lllllll}
\hline \multicolumn{1}{c}{ Managerial Experience } & $\mathrm{N}$ & $\mathrm{X}$ & $\mathrm{ss}$ & $\mathrm{t}$ & $\mathrm{p}$ \\
\hline In-group & Pub. Institution & $\mathbf{9 2}$ & 3.53 & .85 & 4.99 & .ooo* $^{*}$ \\
favoritism & Private Sector & 84 & 2.77 & 1.15 & & \\
Paternal- & Pub. Institution & 92 & 3.16 & 1.16 & 3.60 & $.000^{*}$ \\
chronism & Private Sector & 84 & 2.52 & 1.17 & & \\
$\begin{array}{l}\text { Mutual exchange } \\
\text { of interests }\end{array}$ & Pub. Institution & 92 & 2.87 & .76 & 3.15 & .oo2* $^{*}$ \\
\hline
\end{tabular}

Significant differences were found in sub-dimensions of ingroup favoritism, Paternal chronism, and mutual interest exchange (Table-5).

Significant differences were found in sub-dimensions of Ingroup favoritism, Paternal chronism, and mutual interest 
exchange (Table-6).

Table-3: Comparison of the participants' chronism scale scores according to the variable of position in institution

\begin{tabular}{|c|c|c|c|c|c|c|}
\hline \multicolumn{2}{|c|}{ Position in Institution } & $\mathrm{N}$ & $\mathrm{X}$ & SS & $\mathrm{t}$ & $\mathrm{p}$ \\
\hline In-group & Manager & 35 & 2.35 & .40 & $-5 \cdot 37$ & $.000^{*}$ \\
\hline favoritism & Staff & 141 & $3 \cdot 37$ & 1.09 & & \\
\hline Paternalchronism & Manager & 35 & 1.46 & .09 & -9.24 & $.000^{*}$ \\
\hline & Staff & 141 & 3.20 & 1.10 & & \\
\hline Mutual exchange & Manager & 35 & 1.67 & .60 & -7.71 & $.000^{*}$ \\
\hline of interests & Staff & 141 & 2.90 & .88 & & \\
\hline
\end{tabular}

Table-7: Comparison of the participants' chronism scale scores according to the educational status variable

\begin{tabular}{lllllll}
\hline \multicolumn{1}{c}{ Educational Status } & $\mathrm{N}$ & $\mathrm{X}$ & & $\mathrm{ss}$ & $\mathrm{t}$ & $\mathrm{p}$ \\
\hline In-group & Primary & 7 & 3.00 & .24 & 2.134 & $.040^{*}$ \\
favoritism & High School & 46 & 3.22 & 1.10 & & \\
& Associate Degree & 44 & 3.55 & 1.23 & $\mathrm{c}>\mathrm{d}$ & \\
& Graduate & 66 & 2.93 & 1.02 & & \\
& Post Graduate & 13 & 3.02 & .34 & & \\
Paternal & Primary & 7 & 2.20 & .42 & 1.254 & $.000^{*}$ \\
-chronism & High School & 46 & 2.90 & 1.20 & & \\
& Associate Degree & 44 & 3.60 & .96 & $\mathrm{c}>\mathrm{d}, \mathrm{e}, \mathrm{b}, \mathrm{a}$ \\
& Graduate & 66 & 2.50 & 1.28 & & \\
& Post Graduate & 13 & 2.35 & .72 & & \\
Mutual & Primary & 7 & 2.25 & .32 & 3.546 & $.000^{*}$ \\
exchange & High School & 46 & 2.75 & .68 & & \\
of interests & Associate Degree & 44 & 3.36 & .49 & $\mathrm{c}>\mathrm{d}, \mathrm{e}, \mathrm{b}, \mathrm{a}$ \\
& Graduate & 66 & 2.26 & 1.21 & & \\
& Post Graduate & 13 & 2.23 & .25 & & \\
\hline
\end{tabular}

Significant differences were found in sub-dimensions of In-group favoritism, Paternal chronism and mutual interest exchange (Table-7).

Table-8: Comparison of the participants' chronism scale scores according to the service year variable

\begin{tabular}{|c|c|c|c|c|c|c|}
\hline \multicolumn{2}{|c|}{ ServiceYear } & $\mathrm{N}$ & $X$ & SS & $\mathrm{t}$ & $\mathrm{p}$ \\
\hline \multirow{4}{*}{$\begin{array}{l}\text { In-group } \\
\text { favoritism }\end{array}$} & 1-5 year & 52 & 2.63 & .96 & \multirow[t]{4}{*}{6.721} & $.000^{*}$ \\
\hline & 6-10 year & 69 & 3.36 & 1.05 & & \\
\hline & 11-15 year & 31 & 3.48 & 1.01 & & $b, c, d>a$ \\
\hline & $\geq 15$ & 24 & $3 \cdot 34$ & 1.09 & & \\
\hline \multirow{4}{*}{$\begin{array}{l}\text { Paternal } \\
\text {-chronism }\end{array}$} & 1-5 year & 52 & 2.65 & .87 & \multirow[t]{4}{*}{.824} & .481 \\
\hline & 6-10 year & 69 & 2.95 & 1.36 & & \\
\hline & 11-15 year & 31 & 3.01 & 1.33 & & \\
\hline & $\geq 15$ & 24 & 2.85 & 1.29 & & \\
\hline \multirow{4}{*}{$\begin{array}{l}\text { Mutual } \\
\text { exchange } \\
\text { of interests }\end{array}$} & 1-5 year & 52 & 2.21 & .72 & \multirow[t]{4}{*}{5.882} & $.001^{*}$ \\
\hline & 6-10 year & 69 & 2.76 & 1.13 & & \\
\hline & 11-15 year & 31 & 2.95 & .70 & & $\mathrm{~b}, \mathrm{c}, \mathrm{d}>\mathrm{a}$ \\
\hline & $\geq 15$ & 24 & 2.90 & .91 & & \\
\hline
\end{tabular}

While no significant difference was found in paternal chronism sub-dimension, but significant differences were found in sub-dimensions of In-group favoritism, and mutual interest exchange (Table-8).

While no significant differences were found in paternal chronism sub-dimension and In-group favouritism sub-dimension a significant difference was revealed in sub-dimensions of mutual interest exchange.
Table-9: Comparison of the participants' chronism scale scores according to the age variable

\begin{tabular}{lllllll}
\hline & AgeYear & $\mathrm{N}$ & $\mathrm{X}$ & $\mathrm{ss}$ & $\mathrm{t}$ & $\mathrm{p}$ \\
\hline In-group & $18-25$ & 28 & 3.27 & 1.15 & 2.119 & .100 \\
favoritism & $26-33$ & 44 & 3.37 & 1.06 & & \\
& $34-41$ & 56 & 3.28 & .93 & & $\mathrm{~b}, \mathrm{c}, \mathrm{d}>\mathrm{a}$ \\
& $>42$ & 48 & 3.29 & 1.14 & & \\
Paternal & $18-25$ & 28 & 2.72 & .68 & 2.396 & 0.07 \\
-chronism & $26-33$ & 44 & 2.90 & 1.30 & & \\
& $34-41$ & 56 & 2.91 & 1.22 & & \\
& $>42$ & 48 & 2.56 & 1.30 & & \\
Mutual & $18-25$ & 28 & 2.32 & .72 & 3.563 & 0.015 \\
exchange & $26-33$ & 44 & 2.71 & .88 & & \\
of interests & $34-41$ & 56 & 2.88 & .94 & & b,c,d $>\mathrm{a}$ \\
& $>42$ & 48 & 2.43 & 1.10 & & \\
\hline
\end{tabular}

While no significant differences were found in paternal chronism sub-dimension and In-group favouritism subdimension a significant differences ware found in subdimensions of mutual interest exchange.

\section{Discussion:}

When the scores of the participants in the chronism subdimension according to their gender were examined, significant differences were found in all three subdimensions in favor of women. According to this; it is observed that women have more average chronism in the institution than men. Although there is a significant increase in the employment rate of women in working life in our country, the employment of women in managerial positions is very limited. While there were 56 women participants in the study. Only 1 of them was in a managerial position. This situation may have increased the average of the female participants. In the study conducted on Bornova municipality employees, no significant difference was found in perceptions of chronism by gender (Turhan, 2016). This finding contradicts our findings.

When the scores of the participants in the chronism sub-dimension were examined according to their marital status, significant differences were found in favor of unmarried participants in the sub-dimension of mutual interest. Accordingly, unmarried participants stated that when there is a mutual interest, chronism was experienced more. This situation can be interpreted within the seniority relationship. Unmarried employees consist of people who have spent fewer working years in the organization than married employees. They may have been kept away from bilateral relations as they were newer in the context of relationships within the institution. Due to this situation, it may have been higher for other employees who are less in contact with the mutual interest exchange. Kavak (2020)studied the role of trust in the organization in the influence of perceived organizational chronism on organizational opposition, he found no significant difference between the chronism sub-dimensions of the marital status variable. 
When the scores of the participants in the chronism sub-dimension were examined according to the question of "have you been an administrator?", significant differences were found in favor of managerial in all three subdimensions. This may be because those who do not manage at all have sufficient authority to create chronicles compared to those who are managers.

When the scores of the participants in the chronism sub-dimension were examined according to their institutions, significant differences were found in favor of public employees in all three sub-dimensions. Since private institutions are more competitive than public institutions and have a more competitive performance scale, it may have caused the perception of chronism of public employees to be more than private employees.

According to the answers given by the participants to the question "What is your position in the institution?", when the scores they got from the chronism sub-dimension were examined, significant differences were found in favor of the personnel in all three sub-dimensions. This result coincides with the fact that similar to the answers given to the question "Have you been an administrator before?", it is necessary to have an authority for or to create chronism. In this case, it can be interpreted as personnel managers resort to the phenomenon of chronism.

When the scores of the participants in the chronism sub-dimension were examined according to their seniority in the institution, significant differences were found in a mutual exchange of interests and inner group favoritism. Particularly, employees with the lowest seniority between 15 years stated that they had less perception of chronism than those who work for longer years. In particular, they stated that employees with the lowest seniority between 1-5 years had a lower perception of chronism than those who work for longer years. Kartal (2019), the perceptions of employees of organizational justice and its impact on behavior cronyism in his study on corporate reputation, cronyism subdimensions according to seniority variable and significant differences have been found between the participants working between 1-5 years, with an average of 10-15 participants over theyears were more than.

When the data were examined, in comparing the chronism sub-dimensions to the question of Age of the participants; significant differences were found in subdimensions of mutual interest exchange. Gürer (2017) found a significant difference between the chronism subdimensions according to the age variable, and it was observed that the participants in the 18-25 and 26-35 age groups had a higher average than the participants in the 4655 age group. Polat (2013) stated a significant difference between the chronism sub-dimensions of the age variable and that the perceived chronism level increases as the age getsolder.

As a result, the presence of chronism in the institution is accepted by the employees to be more in the public. Organizations should always use the merit system as a defining concept and provide the element of justice in the workplace. An important criterion for the employees' sense of belonging is performance evaluation. To increase the motivation of the employees, chronism should be avoided while performing the technical evaluation of the work. The source of legitimacy in the structure of modern society was a law and there was no place for favoritism within the law (Kurtoğlu, 2012). The organizational culture in which a sense of justice is ensured will also increase the performance of the employee and thus contribute to the income of the employer.

\section{References:}

Aktan, C.C. (2001): Siyasal Ahlak ve Siyasal Yozlaşma (p. 51-69). Coşkun Can Aktan (Ed.), Yolsuzlukla Mücadele Stratejileri. . Pub. by:Ankara: Hak-İş Yayınları.

Asunakutlu, T. (2010): Kayırmacılığın Temelleri: Benzerlik ve Benzemezlik (p. 41-6o). Ramazan Erdem (Ed.), Yönetim ve Örgüt Açısından Kayırmacılık içinde. Pub. by: Beta Basım, İstanbul.

Aytaç, Ö. (2010): Kayırmacı İlişkilerin Sosyolojik Temeli (p. 3-26). Ramazan Erdem (Ed.), Yönetim ve Örgüt Açısından Kayırmacılıkiçinde. Beta Basim, İstanbul.

Büte, M. (2011): Kayırmacılığın Çalışanlar Üzerine Etkileri İle İnsan Kaynakları Uygulamaları İlişkisi: Türk Kamu Bankalarına Yönelik Bir Araştırma”. Atatürk Üniversitesi Sosyal Bilimler Enstitüsü Dergisi, 15:383-404.

Erdem, M. \& Meriç, E. (2012): Okul Yönetiminde Kayırmacılığa İlişkin Ölçek Geliştirme Çalışması. J. Edu. Sci. Res., 2(2):141154 .

Gürer, A. (2017): Alg1 lanan örgütsel kronizmin çall șan sessizliği üzerindeki etkisinde Kişiliğin düzenleyici rolü: Doktora Tezi, İstanbul Arel Üniversitesi, Sosyal Bilimler Enstitüsü, İstanbul.

Hoy, W.K. \& Miskel, C.G. (2010): Eğitim yönetimi (Çev. Edit. S. Turan). Pub. by: Nobel, Ankara.

Kavak, H. (2020): Alg1 lanan Örgütsel Kronizmin Örgütsel Muhalefet Üzerine Etkisinde Örgüte Güvenin Arac1 Rolü: Ad 1 yaman İlinde Milli Eğitim Bakanl ${ }_{1} \breve{g}_{1}$ na Bağl Orta Öğretim Kurumlarında Bir Araștırma, Doktora Tezi, İnönü Üniversitesi, Sosyal Bilimler Enstitüsü, Malatya.

Kartal, M. (2019): İş hayatındaki kronizm Davranışlarının çalı şanların örgütsel Adalet algı ları na ve kurum itibarı na Etkisi, Band1 rma On Yedi Eylül Üniversitesi, Yüksek Lisans Tezi, Sosyal Bilimler Enstitüsü, Bandırma.

Khatri, N. \& Tsang, E.W.K. (2003): Antecedents and Consequences of Cronyism in Organizations. J. Busi. Ethics, 43:289-303.

Kurtoğlu, A. (2012): Siyasal Örgütler ve Sivil Toplum Örgütleri Bağlamında Hemşehrilik ve Kollamacılık. Ankara Üniversitesi, SBF Dergisi, 67(1):141-169.

Mayer, R.C., Davis, J.H. \& Schoorman, F.D. (1995): An integrative model of organizationaltrusts. Acad. Manag. Rev., 20:709736. 
Polat, R. (2013): Ortaöğretim kurumlarında kronizm algısının örgütsel güven üzerindeki etkisi. Pub. by: Firat Üniversitesi, Egitim Bilimleri Enstitüsü, Egitim Yönetimi, Teftisi, Planlamasi ve Ekonomisi, Anabilim Dali.

Özdemir, A. (2013): Okul yöneticilerindeki adalet ve liyakat ile öğretmenlerdeki sadakat ve gayret arasındaki ilişki. Kuram ve Uygulamada Egitim Yönetimi Dergisi, 19(1):99-117.
Turhan, M. (2013): Organizational Cronyism: A Scale Development and Validation from the Perspective of Teachers. J. Business Ethics. 123:295-308.

Turhan, R. (2016): Nepotizm, kronizm ve patronaj eğilimlerinin kurumsallaşma algısı bağlamında analizi Ege Üniversitesi Sosyal Bilimler Enstitüsü, Doktora Tezi, İzmir.

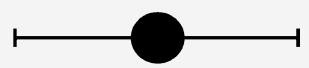

